\title{
MADRASAH SEBAGAI TIPOLOGI LEMBAGA PENDIDIKAN ISLAM (KAJIAN TENTANG BERBAGAI MODEL MADRASAH UNGGULAN)
}

\author{
A. Zuhdi \\ Dosen Tetap Jurusan PAI Fakultas Tarbiyah UIN Maliki Malang
}

\begin{abstract}
"Madrasah" is parth of Islamic boarding school to answer various of polemic in the society, especially in Islamic education development, thus Islamic boarding school able to fuse between subject of religion science and common science. Start from that time, Islamic boarding school establish "madrasah" education under its overshide. "Madrasah" as institute of Islamic education has blossomed out in a time, as emergence of "madrasah"diniyah, "madrasah" of SKB 3 ministers and "madrasah pesantren". From that's models, the great one in development is superior "madrasah". So, unsuprised if there are many schools integrate with Islamic boarding school, that's mean in this concerning school which based on Islamic boarding school able to give satisfactions for stakeholder. Moreover, there are many zest from society to educate their child in madrasah wich based on Islamic boarding school. This can be observed based on social changes. As theory from Etzioni, theory of active society that perceived by continuing changes, but still individu who become member of the society.
\end{abstract}

Keywords: Madrasah, Typology, Islamic education institute and superior

\section{A. Pendahuluan}

Lembaga pendidikan Islam di Indonesia telah ada sejak zaman kerajaan Islam. Pondok pesantren merupakan lembaga pendidikan Islam yang telah berkembang sejak zaman kolonial. Pada awalnya semua pesantren hanya mengajarkan ilmu agama, karena perkembangan pemikiran masyarakat Islam, ada kalangan umat Islam yang merasa tidak puas dengan sistem pesantren maka mendirikan madrasah (Karel A. Steenbrink, 1986: 43). Kelahiran madrasah merupakan bentuk ketidakpuasan umat Islam dengan sistem pesantren yang hanya menitikberatkan pada pelajaran agama, tanpa menghiraukan pelajaran umum. Madrasah mengajarkan secara berimbang antara ilmu agama dan ilmu umum, dengan perpaduan antara sistem pesantren dengan klasikal (Mahpuddin Noor, 2006: 55). Madrasah pertama di Indonesia adalah madrasah Adabiyah di Padang Sumatra Barat, yang pada mulanya hanya mengajarkan ilmu agama kemudian setelah beberapa tahun kemudian baru mengajarkan 
pengetahuan umum. Konon madrasah Adabiyah, merupakan madrasah yang pertama kali yang mengajarkan tentang pengetahuan umum.

Seiring dengan industrialisasi dan modernisasi maka globalisasi tidak dapat dibendung lagi. Untuk itu, madrasah-madrasah banyak mengalami pengembangan dan inovasi untuk menyesuaikan dengan tuntutaan zaman. Pengembangan madrasah harus dilakukan sesuai dengan kondisi masyarakat yang terus mengalami perubahan untuk lebih kemajuan. Seperti halnya yang dijelaskan Auguste Comte perubahan masyarakat terjadi menurut kemajuan. Comte melihat kemajuan terjadi di setiap segi tata masyarakat, termasuk fisik, etika, pikiran dan politik serta tingkat kemajuan manusia dipengaruhi oleh beberapa faktor (Robert H. Lauer, 2000: 74-75).

Dari perubahan masyarakat ini mengharuskan madrasah melakukan berbagai inovasi agar madrasah tetap survive dan menjadi pilihan masyarakt. Inovasi yang telah dilakukan beberapa madrasah, melahirkan bentuk madrasah yang berbeda-beda, baik dalam sistem pembelajarannya ataupun dalam hal praktek pembelajarannya. Untuk itu dalam tulisan ini akan dibahas tentang beberapa tipologi lembaga pendidikan Islam terutama tipologi madrasah. Karena dalam pembahasan ini lebih difokuskan perkembangan madrasah, utamanya madrasah unggulan.

\section{B. Madrasah sebagai Lembaga Pendidikan Islam}

Madrasah merupakan tempat pendidikan yang memberikan pendidikan dan pengajaran agama maupun umum, yang berada di bawah naungan Kementerian Agama RI. Madrasah berasal dari kata Arab yang artinya tempat belajar. Madrasah didirikan karena ketidakpuasan masyarakat dengan sistem pesantren, jadi lahirnya lembaga ini merupakan kelanjutan dari sistem pendidikan pesantren dengan lama yang dimodifikasi dengan model penyelenggaraan sekolah-sekolah umum dengan sistem klasikal. Di samping memberikan pengetahuan agama juga memberikan pengetahuan umum.

Pada masa awal berdirinya, madrasah lebih banyak mengajarkan ilmu-ilmu agama dari pada ilmu-ilmu umum. Namun keadaaan ini terjadi perubahan setela keluarnya SKB 3 Menteri yaitu Menteri Agama, Manteri Pendidikan dan Kebudayaan, dan Menteri Dalam Negeri, maka madrasah mengubah kurikulumnya menjadi 70\% bidang studi umum dan $30 \%$ bidang studi agama. Hal ini dilakukan pada madrasah negeri tetapi bagi madrasah swasta berfariasi ada yang menerapkan sesuai SKB 3 
Menteri atau $40 \%$ bidang studi umum dan $60 \%$ bidang studi agama. Semua ini dilakukan agar ijazah dari madrasah mempunyai nilai sederajat dengan sekolah umum atau civil effect, sehingga lulusan madrasah dapat melanjutkan ke seklah umum setingkat lebih atas.

Namun dalam perkembangannya madrasah menimbulkan problema sendiri, yaitu pendidikan Islam tidak dapat dikatakan secara utuh sebagai sistem pendidikan yang mandiri seperti pesantren atau madrasah pada kolonial. Dengan adanya SKB 3 Menteri kebijakan madrasah selalu berubah mengikuti pola perubahan yang terdapat di sekolah umum, ketergantungan pada sekolah umum sengat besar. Akan tetapi beberapa tahun terakhir madrasah mulai banagkit dan sedikit melepaskan ketergantungannya pada sekolah umum. Hal ini terlihat, dahulu dalam menyelenggarakan Ujian Nasional (UN) madrasah selalu mengikuti sekolah umum madrasah tidak bisa menyelenggarakan ujian sendiri, sedangkan saat ini madrasah sudah bisa menyelenggarakan Ujian Nasional (UN) di lembaga itu sendiri.

Perkembangan lebih lanjut, setelah kurang lebih berjalan 20 tahun sejak berlakunya SKB 3 Menteri harapan yang dicanangkan semula tidak tercapai, yakni berkaitan dengan kualitas dan kuantitas tenaga penagajar, kualitas dan kuantitas sarana dan prasarana, kesemua itu berada di bawah standar sekolah-sekolah umum, walaupun dapat dinyatakan lebih baik bila dibandingkan sebelum SKB 3 Menteri. Dengan keadaan tersebut sudah barang tentu mengakibatkan mutu pendidikan madrasah lebih rendah dengan pendidikan di sekolah umum. Sebenarnya keadaan ini tidak harus terjadi, bila pengelolaan dan pembinaannya lebih ditingkatkan lagi dan lobang-lobang kekurangan yang ada segera diperbaiki baik yang menyangkut tenaga pendidik dan lain sebagainya (M. Ridwan Nasir, 2006: 90-94).

Dalam beberapa tahun terakhir ini madrasah mencoba untuk melakukan banyak perubahan dan pengembangan sistem pendidikan dan kelembagaan, sehingga kepercayaan masyarakat dapat meningkat. Hal ini terlihat dengan munculnya lembaga pendidikan Islam yang bermutu dan menjanjikan seperti sekolah al-Azhar, madrasah yang ada di jalan Bandung Kota Malang yaitu Madrasah Ibtidaiyah Negeri Malang I, MTsN Malang dan MAN 3 Malang, al-Hikmah Surabaya, dan masih banyak madrasah yang setara dengan tersebut di atas (A. Malik Fadjar, 2005: 10). Pengembangan pendidikan Islam bukanlah hal yang sederhana karena memerlukan adanya perencanaan secara terpadu dan menyeluruh. Untuk itu belum semua lembaga 
pendidikan Islam mampu melakukan hal ini. Hanya beberapa pemimpin saja yang mampu untuk melakukan terobosan-terobosan untuk memajukan madrasah yang dipimpinnya.

\section{Model Madrasah dalam Lembaga Pendidikan Islam}

Model madrasah dalam lembaga pendidikan Islam, sebagaimana dijelaskan di atas bahwa madrasah adalah bentuk lembaga pendidikan yang muncul sebagai kelanjutan dari pendidikan pesantren yang memadukan pendidikan pesantren dan pendidikan sekolah umum, dengan itu diharapkan dapat membentuk siswa yang mempunyai kemampuan agama dan pengetahuan umum.

Menurut M. Ridwan Nasir, berdasarkan kurikulumnya madrasah dapat dibagi menjadi tiga jenis yaitu: madrasah Diniyah, Madrasah SKB 3 Menteri dan madrasah pesantren. Dari ketiga jenis madrasah tersebut diuraikan yaitu: Pertama, madrasah diniyah. madrasah diniyah adalah suatu bentuk madrasah yang hanya mengajarkan ilmu-ilmu agama (Diniyah). Madrasah ini dimaksudkan sebagai lembaga pendidikan agama yang disediakan bagi siswa yang belajar di sekolah umum. Madrasah ini siswasiswa sekolah dasar (4 tahun). Madrasah Diniyah Wustho unuk siswa-siswi sekolah lanjutan pertama (3 tahun). Orang tua memasukkan putra-putrinya ke madrasah ini agar putranya mendapat tambahan pendidikan agama, karena di sekolah umum dirasakan masih sangat kurang. Ijazah madrasah ini tidak memiliki civil effect, dan proses pembelajaran dilaksanakan pada sore hari.

Kedua, madrasah SKB 3 Menteri. Madrasah ini tidak lepas dengan setelah keluarnya SKB 3 Menteri, beberapa madrasah Diniyah memasukkan pelajaran umum dan yang sekarang berkembang menjadi Madrasah Ibtidaiyah, Madrasah Tsanawiyah dan Madrasah Aliyah. Sebagai upaya peningkatan mutu pemerintah member berbagi bantuan seperti buku ajar, dana rehab bangunan, laboratorium dan sebagainya.

Ketiga, madrasah pesantren. Madrasah pesantren, madrasah ini adalah madrasah yang memakai sistem pondok pesantren, siswa tinggal di pondok selama 24 jam sehari semalam dengan suasana belajar. Bila ditinjau dari segi kurikulumnya, madrasah pesantren ini dibagi menjadi dua macam yaitu; Pertama, seluruh kurikulumnya diprogramkan dan diatur oleh pondok pesantren sendiri. Kedua, mata pelajaran umum sesuai dengan kurikulum madarsah SKB 3 Menteri, sedangkan mata pelajaran agamanya diprogramkan dan diatur oleh pondok pesantren, dengan tetap 
memperhatikan kurikulum madrasah SKB 3 Menteri maka siswa-siswi dilakukan Ujian Negara (M. Ridwan Nasir, 2006: 95-102).

Pada madrasah SKB 3 Menteri yang biasa disebut madrasah, maka madrasahmadrasah yang ada berbagai macam bentuknya, yang kadang disebut madrasah pinggiran dan madrasah model (madrasah unggulan). Madrasah pinggiran, madrasah yang ada di daerah pinggiran kota dengan gedung-gedung sekolah dan fasilitas yang segi kualitas dan mutu pendidikan madrasah pinggiran masih memprihatinkan, kemerosotan kualitas pendidikan madrasah pinggiran lantaran input siswa bukan dari siswa yang terbaik, dan proses pembelajaran berjalan apa adanya karena mengalami berbagai keterbatasan. Sedangkan madrasah model (madrasah unggulan) adalah madrasah yang didesain sebagai pusat percontohan bagi madrasah yang ada di sekitarnya, baik dalam bidang kurikulum, mutu kelembagaan, maupun proses dan fasilitas serta sarana dan prasarana yang lengkap dan memadai serta sumber daya guru atau mutu guru belajar yang ideal, kreatif dan inovatif. Madrasah model ini banyak ditemui di kota-kota besar atau di pusat kota.

Madrasah-madrasah unggulan yang bermunculan memiliki berbagai konsep, dari konsep yang dikembangkan sehingga muncul beberapa model atau tipe. Menurut Moedjiarto, sekolah-sekolah unggulan yang bermunculan saat ini dapat dikategorikan ke dalam beberapa tipe, yaitu: Pertama, input siswa unggul, proses belajar mengajar tidak luar biasa maka dapat diduga lulusan dapat bermutu unggul. Keunggulan lulusan sekolah ini memang merupakan bawaan sebelum siswa masuk sekolah tersebut. Kedua, sekolah unggul dalam hal fasilitas, karena fasilitas lengkap maka biaya yang harus dikeluarkan juga mahal. Sekolah dengan fasilitas lengkap seperti ini diharapkan daya tahan siswa untuk belajar bisa lebih lama. Gurunya juga pilihan, dengan harapan proses belajar mengajar akan berjalan dengan lancar dan lulusannya juga bermutu tinggi. Pada sekolah unggul seperti prestasi akademik siswa, input yang unggul bukan persyaratan yang utama. Ketiga, sekolah unggul jenai lain adalah yang penekanannya iklim belajar yang positif di lingkungn sekolah. Sekolah yang mampu memproses siswa bermutu rendah (input rendah), menjadi lulusan yang bermutu tinggi (output tinggi). Tipe madrasah yang ketiga yang biasa disebut dengan effective school (Moedjiarto, 2007: 3-6).

Tipe-tipe tersebut di atas tidak hanya untuk sekolah-sekolah umum yang unggulan, akan tetapi pada lembaga pendidikan Islam atau madrasah-madrasah di 
lingkungan lembaga pendidikan Islam di Indonesia. Karena pada sekarang sekolah yang notabeninya unggul tidak hanya dimiliki oleh sekolah umum, namun di lembaga pendidikan Islam banyak lembaga pendidikan yang maju, yang dalam hal ini adalah madrasah baik madrasah yang statusnya negeri maupun swasta.

\section{Analisis tentang Model Madrasah Unggul}

Jika diperhatikan secara seksama bahwa hampir setiap kota besar bermunculan madrasah-madrasah model atau madrasah unggulan dengan konsep yang beragam. Madrasah seperti inilah yang saat ini banyak diminati oleh masyarakat meskipun harus mengeluarkan biaya yang mahal. Madrasah yang unggulan bukan hanya fasilitas yang lengkap tetapi juga Sumber Daya Manusia (SDM) yang berkualitas. Sehingga dengan fasilitas yang memadai dan sumber daya manusia juga berkompeten dalam bidang yang sesuai dengan mata pelajaran yang diajarkan di kelas masingmasing.

Menoleh pada lembaga pendidikan Islam yang ada di jalan Bandung Kota Malang yang berurutan baik dari TK, Madrasah Ibtidaiyah Negeri Malang I, Madrasah Tsanawiyah Negeri Malang, dan Madrasah Aliyah Negeri 3 Malang. Dalam hal ini MIN Malang I merupakan salah satu madrasah unggulan tingkat dasar yang banyak diminati masyarakat Malang pada khususnya dan masyarakat luar Malang. Untuk dapat diterima di MIN Malang I, kemampuan siswa harus unggul, siswa mampu calistung. Di samping itu juga biaya yang dikeluarkan cukup besar bila dibandingkan sekolah negeri lain pada tingkat dasar. Besarnya biaya tersebut karena fasilitas yang tersedia untuk belajar mengajar lengkap. MIN Malang I jika dianalisa berdasarkan konsep Moedjiarto dapat dikategorikan sekolah unggulan merupakan gabungan dengan tipe 1 dan tipe 2 .

Di kawasan daerah-daerah pinggiran kota mulai dikebangkan madrasah unggulan yang menurut Moedjiarto tipe 3. Input siswa biasa, dari proses pembelajaran diharapkan dapat menjadikan output bermutu. Salah satunya MIN Locare Bondowoso, kemampuan input siswa biasa dan sebagian besar perhatian orang tua terhadap pendidikan kurang. Guru berusaha untuk meningkatkan mutu dengan mengoptimalkan kelebihan yang dimiliki madrasah yaitu dengan tenaga guru yang cukup dan memiliki kualifikasi keilmuan yang memadai, serta letak madrasah yang strategis dan mudah dijangkau. Dengan ketulusan hati dan keteguhan jiwa para 
pendidik MIN Locare, kini telah menjuarai beberapa prestasi tingkat kebupaten (Mimbar Pembangunan Agama, 2006: 27).

Selain madrasah seperti di atas, saat ini juga banyak dikembangkan madrasah pesantren. Madrasah yang ada di pesantren dengan kurikulum yang disusun sendiri oleh pesantren seperti madrasah Muallimin dan Muallimat Bahrul Ulum Tambakbears Jombang. Madrasah Muallimin dan Muallimat adalah salah satu pendidikan formal berada di bawah naungan Yayasan Pondok Pesantren Bahrul Ulum Tambakbears Jombang, yang mempunyai cirri-ciri khusus dalam pengembangan ilmu-ilmu keagamaan Islam. Kurikulum yang dikembangkan hasil dari modifikasi dari para pengasuh yang bobot perbandingannya tentu lebih banyak agama dibanding umumnya. Akan tetapi mata pelajaran umum juga disesuaikan MAN untuk kelas IV sampai VI dan disesuaikan dengan MTsN bagi kelas I sampai kelas III. Untuk itu siswa kelas III madrasah Muallimin dan Muallimat dapat mengikuti ujian Tsanawiyah Negeri dan untuk kelas VI dapat mengikuti ujian Madrasah Aliyah Negeri. Dalam penerimaan murid baru dilakukan seleksi kemampuan mata pelajaran bahasa Arab dan segala cabangnya, kemampuan mambaca kitab kuning dan kemampuan membaca al-Qur'an (M. Ridwan Nasir, 2006: 216-222).

Madrasah model atau madrasah pesantren banyak diminati masyarakat dan banyak dikembangkan oleh para pengelola pendidikan, khususnya lembaga pendidikan Islam. Hal ini dapat diamati berdasarkan perubahan sosial. Sebagaimana teori yang ditawarkan oleh Etzioni, teori masyarakat aktif yang merupakan suatu masyarakat yang ditandai oleh perubahan terus menerus, akan tetapi individu yang menjadi anggota masyarakat (Robert H. Lauer, 2000: 180). Karena dalam mlakukan perubahan tersebut pengelola lembaga pendidikan Islam (madrasah) selalu melakukan usaha secara maksimal yang mengarah pada mutu madrasah yang unggul. Salah satu untuk menjadikan madrasah yang unggul adalah (1) kondisi kelas yang nyaman, asri, dan kondusif untuk kegiatan pembelajaran. (2) proses pembelajaran selalu mengacu pada sistem aktif, kreatif, dan inovatif. (3) Pembelajaran dengan berbasis ITF (Farid Hasyim, 2009: 55).

Dari salah satu mutu madrasah atau madrasah unggulan tersebut di atas, maka jelas bahwa model madrasah unggulan sangat diminati oleh masyarakat untuk menyekolahkan anaknya ke madrasah yang unggul, meskipun biayanya sangatlah 
tinggi. Dengan demikian, maka madrasah yang unggul mampu memberikan lulusan yang berkualitas baik dari akademik siswa maupun non akademik siswa.

\section{E. Penutup}

Perubahan lembaga pendidikan Islam dari masa ke masa tidak lepas dengan kemajuan IPTEK dan globalisasi yang semakin cepat sangat mempengaruhi perubahan masyarakat, begitu juga masyarakat Indonsia. Perubahan masyarakat ini menjadikan sistem pendidikan juga harus mengalami perubahan, tidak terkecuali pendidikan Islam. Dan sebagai bentuk perubahan dan inovasi pendidikan Islam telah muncul madrasah pesantren, madrasah model atau madrasah unggulan dengan berbagai tipe madrasah yang unggul.

Madrasah yang unggul adalah madrasah yang mempunyai program-program unggul yang lahir dari sebuah keinginan untuk memiliki madrasah yang mampu berprestasi di tingkat nasional maupun dunia dalam penguasaan ilmu pengetahuan dan teknologi serta yang ber-akhlakul karimah. Madrasah model atau madrasah unggulah ini mampu memberikan daya tarik tersediri bagi masyarakat untuk menyekolahkan anaknya ke madrasah yang unggul meskipun dengan biaya yang sangat mahal. Dengan demikian, maka madrasah yang unggul mampu memberikan lulusan yang berkualitas baik dari akademik siswa maupun non akademik siswa.

\section{F. Daftar Pustaka}

Fadjar, A. Malik. (2005). Madrasah dan Tantangan Modernitas. Jakarta: Mizan. Hasyim, Farid. (2009). Strategi Madrasah Unggul. Yogyakarta: Prismasophie. Lauer, Rober H. (2000). Perspektif tentang Perubahan Sosial, Jakarta: Rineka Cipta. Mimbar Pembangunan Agama (MPA), No. 237 Juni 2006 Moedjiarto. (2007). Karakteristik Sekolah Unggul. Jakarta: Duta Graha Pustaka. Nasir, M. Ridwan. (2006). Mencari Tipologi Pendidikan Ideal. Yogyakarta: Pustaka Pelajar. Noor, Mahpuddin. (2006). Potret Dunia Pesantren: Lintasan Sejarah, Perubahan dan Perkembangan Pondok Pesantren. Bandung: Humaniora.

Steenbrink, Karel A. (1986). Pesantren, Madrasah, Sekolah. Jakarta: KP3ES. 